\title{
Designing Walking Pathways for a Tourist Resort with the Theory of Six Value Aggregation Paths
}

Abstract: The study examines the possibility of applying the selected components of the theory of six value aggregation paths in designing walking pathways. Based on spatial data collected using a landscape assessment method on the aesthetic values of the landscape of the place under analysis, a model was developed of the network of links of the landscape aesthetic value using a minimum increase in this value. The authors designed scenarios for the optimal routes of walking pathways. The conducted study leads to the conclusion that the minimum value increase path may create a good basis for designing walking pathways. Not only is this manifested in the varied route of the pathway, but also in it being designed in such a way that the landscape's aesthetic value increases beyond an assumed level of aesthetic value. In addition, the use of hexagonal basic fields enables the design of various route lengths and the optimization of time by adapting the model to a specific group of recipients.

Keywords: GIS, open source, theory of six value aggregation paths, walking pathways, network, model, map, landscape, aesthetic value

Received: 14 December 2020; accepted: 24 February 2021

(C) 2021 Author. This is an open access publication, which can be used, distributed and reproduced in any medium according to the Creative Commons CC-BY 4.0 License.

1 University of Warmia and Mazury in Olsztyn, Faculty of Geoengineering, Institute of Geodesy and Building Engineering, Department of Geodesy, Olsztyn, Poland, email: anna.kowalczyk@uwm.edu.pl, ORCID ID: https://orcid.org/0000-0002-4580-7479 


\section{Introduction}

The landscape, which is an aesthetic expression of the condition of the environment, is the basic assessment criterion for a tourist, i.e. a person paying a visit as well as inhabitants of a particular locality. This assessment affects the assigned landscape's aesthetic value and determines whether or not a particular place is more willingly visited, whether or not it meets the aesthetic expectations and whether or not it is disappointing.

The idea of establishing tourist trails [1], including walking or nature-educational pathways, not only results from the necessity to apply various forms of educating the society that promote the development of pro-environmental attitudes, but also from the needs resulting from the definition of sustainable development, including the need for the optimization of the use and development of environmental and aesthetic values of the place, based on scientific methods [2, 3].

Walking pathways should be designed to enable the development of the ability to observe one's surroundings and nature, to stimulate the user's aesthetic sensitivity and to make optimal use of (manage) the aesthetic value of the landscape of the area and protect it. In addition, these pathways should also serve an educational function. The subject matter may oscillate around one or several problems and the presented topics may concern the history of a particular place, environmental and landscape protection, botany, local handicraft, etc. Marked routes should be part of the transport system to allow tourism traffic to be directed [4]. The particularly important principles of designing walking pathways, including educational ones, are as follows [5]:

- the route should be varied and, preferably, circular in nature; it should be diverse, and include interesting sites and natural peculiarities;

- the topics representing selected issues in an illustrative manner should be attractive;

- the pathway should be connected into a logical sequence using the gradual development of program assumptions and offering the opportunity to draw independent conclusions;

- the selection and presentation of pathway components, as well as the length of the route, should enable the passage of the pathway, including stops, in approx. 2-3 hours (variants of longer and shorter routes can be developed);

- demonstration points (presenting various themes, and serving an educational function) should be distributed at various distances (at least $100 \mathrm{~m}$ ), depending on local conditions;

- the number of planned thematic waypoints should be adjusted to the average visitor's perception capabilities;

- the pathway marking should facilitate spatial awareness, and the equipment components should be selected according to the intended use of the pathway; 
- the design and implementation of the project should provide the opportunity to prepare the optimum form of presentation of the pathway in the form of, an e.g. educational guide, or training materials including a list and description of demonstration points and a sketch of the route.

Moreover, Ptaszycka-Jackowska and Baranowska-Janota [6] point out that the route should be designed in such a matter that it makes use of the existing road and path network, the visiting route should be properly marked, and selected points should emphasize the landscape's aesthetic and natural values (while not encouraging tourists to stray from the trail) [5].

The study aimed to examine the possibility of applying the selected components of the theory of six value aggregation paths in designing walking pathways, based on the specific example of a tourist resort. The study presented below focused on the optimization of designing walking pathways by making use of the aesthetic value of the landscape of the particular place intended for active recreation. The area under analysis was a selected part of the city of Mragowo situated in north-eastern Poland. The spatial development structure of this place is largely determined by the geographical location and the landscape and natural conditions. Favorable natural conditions that create the attractive environment and the interesting and varied landscape include numerous lakes located within the town and in its vicinity and hills of glacial origin, including the Wyszembork Elevation that has a direct effect on microclimate in the town and in the immediate vicinity (forests and water bodies occupy $1 / 3$ of the town area). The area under analysis represents not only an urban cultural landscape but also the lacustrine landscape (including forest complexes). The part subjected to the analysis was the center of Mragowo, which is most often visited by tourists. It was assumed that the proposed pathways would ultimately be rather short, as they are supposed to be travelled by an average tourist or town inhabitant in an optimal manner, and should not require them to spend too much time doing so. It should be stressed that the developed materials are intended to be the starting materials for designing walking pathways and should be consulted with the actors involved in designing and developing the particular locality and that they should be subject to public consultation.

\section{Assessment of the Landscape's Aesthetic Value}

There are numerous methods of landscape assessment and valuation. Cymerman, Falkowski, and Hopper [7] distinguish three groups of landscape assessment methods. The first method comprises methods based on the assessment of the natural value of individual environmental components. The next method includes methods based on the assessment of the landscape's aesthetic and visual values, while the third method is comprised of the methods assuming the landscape valuation for 
a specific purpose [7]. Bajerowski, however, proposes a slightly different division of the method of landscape assessment and valuation and divides them into five groups [8]. This division is presented in Figure 1.

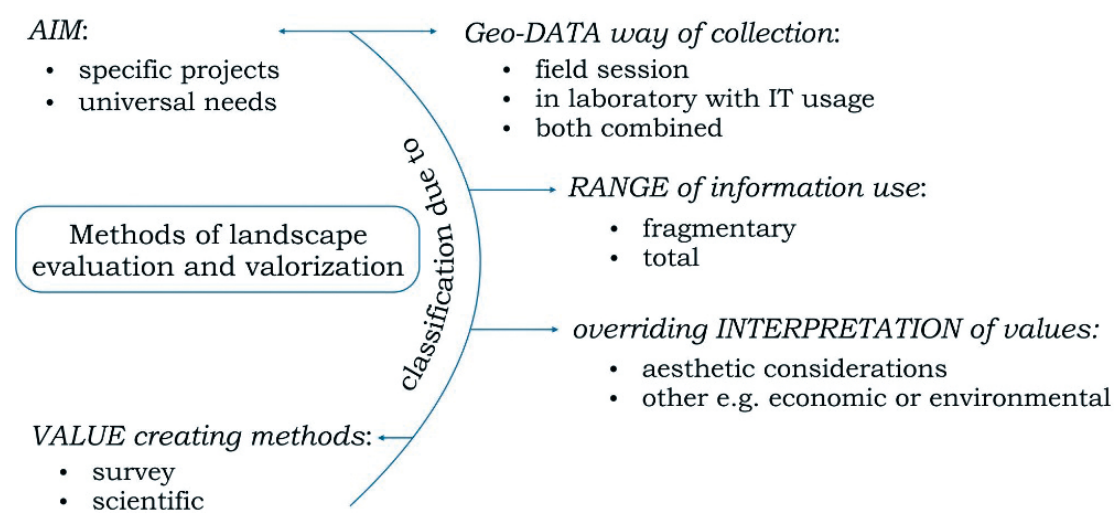

Fig. 1. The classification of methods of landscape assessment and valuation, and the path of determining (selecting) the method depending on its purpose

Source: [8]

The methods of landscape assessment and valuation were described by Bogdanowski [9], Arthur et al. [10], Zube et al. [11], Hopfer et al. [12], Wojciechowski [13], Cymerman et al. [7], Bajerowski [14-15], Kowalczyk [16], Senetra [17], Senetra and Cieślak [18], Aguilera et al. [19], Balon and Krąż [20], Kowalczyk [21] and Tveit et al. [22].

According to Krause [23], there are some important criteria for evaluating a landscape: landscape image, identity and its natural or cultural variety. To retain these elements, scientists develop methods of analyzing and demonstrating a structure and image of landscapes, based on the ranking of landscape features and individual expression of partial image sectors, including testing the impairment of coherent features [23-25]. The development of IT and GIS tools has led to an increase in the choice of methods basing on landscape modeling [26-28] and on creating simulations of changes which can occur in the aesthetic quality of a given landscape after the introduction of changes [29-32].

Walkability is another interesting motif within the aspect of the research, as well as the usage of GIS tools. It conditions the accessibility to landscape observation in a given location. This issue is discussed by Telega et al. [33]. The researchers support the urban planning process by considering important quantitative and qualitative aspects of walkability in the cities [34].

Since the test area for conducting the study is a town, the data for developing models of the landscape's aesthetic value network were acquired using the impression curve method modified by Bajerowski. 
The method was originally developed by Wejchert for the assessment of visual attractiveness of a city center's space-time passageways. Landscape assessment by this method is rather accessible in technical terms, yet it requires the assessor to have a great deal of knowledge of the theory of aesthetics as well as a developed sense of perception [35]. The impression curve method involves the graphical representation of the tension of impressions and emotional sensations experienced by an observer when moving through the space-time passageway. The assessment technique consists in describing, using an appropriately selected scale, the intensity of impressions at specified intervals or after a certain distance has been covered when walking along the route. The impressions and sensations are to be indicated on a graph, where the horizontal axis is the temporal and linear scale on which subsequent scenic points are placed, as assessed by the observer when walking along the route [18]. On the vertical axis, the observer indicates the tensions of the impressions arising from the assessment of landscapes of different values. The resulting curve of impressions should be read as an illustration of average impressions for which no measurement unit can be established, as it is only a means of comparing individual parts of the landscape.

Both the structuralisation and assessment of an urban space were largely contributed to by a study conducted by Lynch [36], who introduced both the concept and the method of cognitive mapping. The cognitive map method is mostly based on perceiving a place in the environmental psychology aspect, and is mainly criticized for the difficulties in mapping the space being assessed. Unlike Lynch, Wejchert describes a sum of certain components that can be found within a particular area. They organize the space, and the relationships between them may be subject to an assessment [37]. Similarly, Böhm presents the opportunity to use an analysis of urban interiors to assess the urban environment [38].

The above-described impression curve method is simple and clear and assesses the landscape in terms of aesthetic aspects. It can be used to create a scenic point network through landscape design processes by means of removing and/or adding new components. It appears to be particularly appropriate in towns and cities which are predisposed and have natural conditions for the development of tourism and recreational functions.

The proposals to modify Wejchert's impression curve method are described by Bajerowski $[8,15]$. The modification involves:

- marking out the route along the landscape boundaries determined in accordance with the principles described in the method proposed by Wejchert;

- a technical convenience i.e. the assessor marks the comparison of his/her impressions and aesthetic sensations experienced when staying at a particular post with the sensations experienced at other posts; the recording is done using arrows, on a specially developed diagram which is in a matrix form (Tab. 1); such an approach eliminates difficulties in determining the landscape's values on an arbitrarily adopted scale and enables the performance of this assessment by mathematical processing of the observation results. 
An example of the assessment method is provided in Tables 1 and 2.

Table 1. A diagram of landscape assessment by the method modified by Bajerowski - an example

\begin{tabular}{|c|c|c|c|c|c|c||}
\hline $\mathrm{x}$ & 1 & 2 & 3 & 4 & 5 & $\sum$ points \\
\hline \hline 1 & $\mathrm{x}$ & $\leftarrow$ & $\leftarrow$ & $\uparrow$ & $=$ & 5 \\
\hline 2 & $\uparrow$ & $\mathrm{x}$ & $=$ & $\leftarrow$ & $\leftarrow$ & 5 \\
\hline 3 & $\uparrow$ & $=$ & $\mathrm{x}$ & $\leftarrow$ & $=$ & 4 \\
\hline 4 & $\leftarrow$ & $\uparrow$ & $\uparrow$ & $\mathrm{x}$ & $\uparrow$ & 2 \\
\hline 5 & $=$ & $\uparrow$ & $=$ & $\leftarrow$ & $\mathrm{x}$ & 4 \\
\hline
\end{tabular}

Source: [8]

The numbers in the first column and the first line indicate the number of the post for the assessment of landscape's aesthetic value and are the individual points of the designated route. The assessment should be carried out for both the left and right side of the route. The matrix is symmetrical, which enables convenient data entry, with the possibility for entering the data from the diagonal under in-house conditions. The comfort of application is also provided by the simple system of assessment recording using symbols $(\uparrow,=, \leftarrow)$, which minimizes the possibility of an error.

Table 2. An example of designation and the scale of landscape assessment values in a comparison matrix

\begin{tabular}{|c|c|l||}
\hline \hline Symbol & Points & \multicolumn{1}{|c|}{ Description of significance } \\
\hline \hline$\leftarrow$ & 2 & landscape more valuable than... (e.g. at point 1 it is more valuable than at point 2) \\
\hline$=$ & 1 & landscape as valuable as... (e.g. at point 2 it is as valuable as at point 3) \\
\hline$\uparrow$ & 0 & landscape less valuable than... (e.g. at point 4 it is less valuable than at point 5) \\
\hline
\end{tabular}

Source: own study based on [8]

By summing up the points (in the example provided, in the lines), the data for plotting the impression curve and, thus, the statistics of scenic point assessment, are obtained.

\section{Data for the Construction and Analysis of the Network Model}

From a scientific point of view, the assessment of a landscape's aesthetic value can be carried out by using basic assessment fields. The landscape's aesthetic value assigned to a particular field is regarded as geospatial data, i.e. data with a precisely specified geographic location. This means that the specific aesthetic value of the 
landscape, assigned to a basic assessment field, represents this spatial unit. Balon and Krąż [36], Bajerowski et al. [8] and Kowalczyk [21] provide more information on basic assessment fields. This study collected the data on the landscape's aesthetic value by the impression curve method modified by Bajerowski. The points for the assessment of landscape's aesthetic value were determined based on geometric basic assessment points, i.e. hexagons. Basic assessment points in the shape of hexagons are used to develop the so-called hexbin maps by the binning method [39].

A grid of 100 hexagons, each with an area of approx. 1.3 ha, was plotted onto the area under analysis (a part of the town of Mragowo). Since a lakeside area was selected, the field grid was modelled in relation to the shoreline in order to exclude the water area when marking out the route, with the condition of a compact field arrangement. When marking out the route, efforts were made to preserve the walking trail marked out by the passageways of the selected area. At particular waypoints, an assessment was conducted of the left and right side and the maximum value from these assessments was considered in the final model. To avoid a situation where only previously seen elements are compared with each other, the persons evaluating the aesthetic value should beforehand become acquainted with the terrain. The assessment diagram yielded data on the landscape's aesthetic value for further analysis, i.e. the construction of a network model and designing walking pathways. A hexbin map of the aesthetic value in the area under analysis is provided in Figure 2.
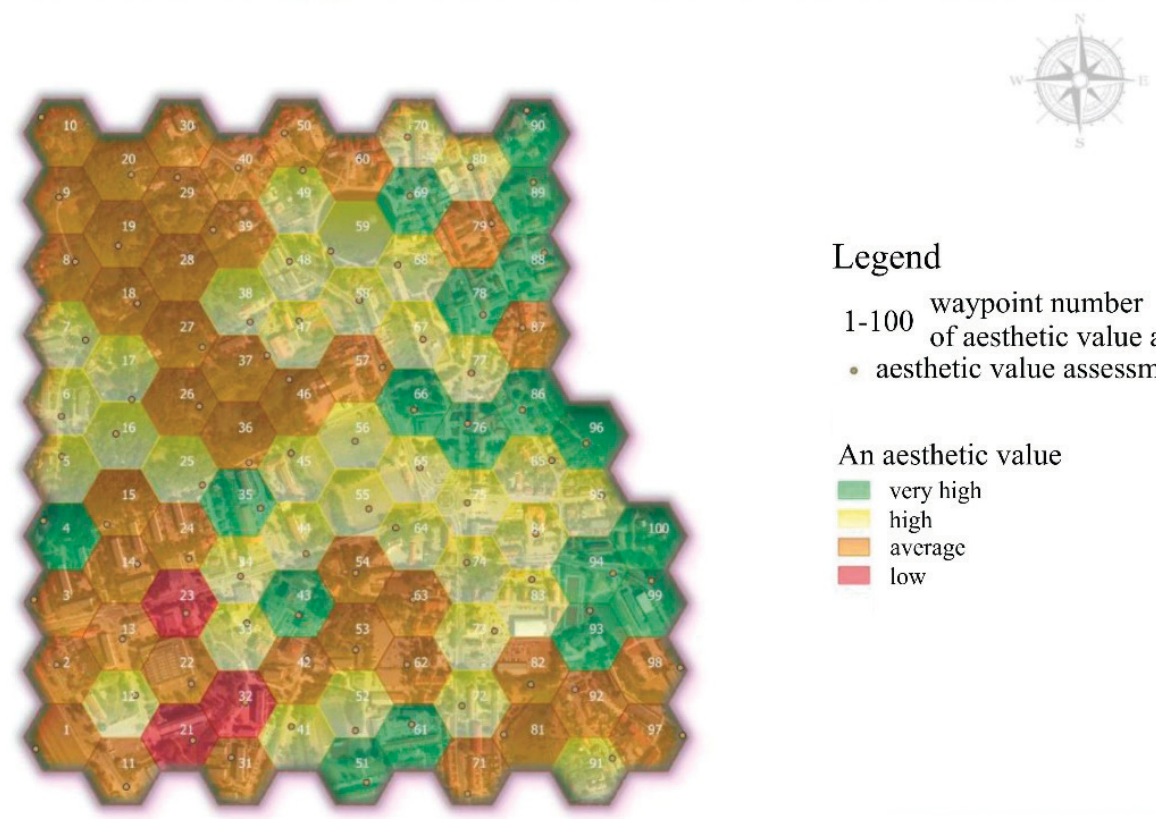

\section{Legend}

1-100 $\begin{aligned} & \text { waypoint number } \\ & \text { of aesthetic value assessment }\end{aligned}$

- aesthetic value assessment points

Fig. 2. A hexbin map of the landscape's aesthetic value in the area under analysis. A part of the town of Mragowo. An analysis made in QGis 
The diversity of the space and, consequently, assigning different values to the basic assessment fields, determines its components to establish connections, i.e. to create the network structure.

\section{Theory of Six Value Aggregation Paths}

According to the theory of six value aggregation paths, the basis of the network organization of space is its diversity [40]. This theory assumes that it is the spatial diversity that generates six types of interactions, i.e. connections of geospatial data. The combination of values (spatial data) which represent the space may occur according to the following paths: minimum or maximum value difference, minimum or maximum value decrease and minimum or maximum value increase. For the purposes of carrying out this study, a landscape's aesthetic value network model was developed using the path of a minimum increase in this value. It was assumed that the path was optimal since the pathways should preferably be designed in such a manner that the aesthetic sensations experienced by a person walking along the pathway should be increasing and not decreasing. In addition, a minimum increase in the landscape's aesthetic value guarantees that full use will be made of this value's potential. The pathways can be designed in such a manner so that this value increases gradually with no considerable differences, as would be the case in the event of a maximum increase in the value.

In each of these paths, new regions emerge due to the generation of a connection between each field and a field that has a common boundary (a neighboring one), if a particular relationship of value difference, increase or decrease, has occurred. The theory assumes that each field can establish a connection with only one neighboring field. The values that represent a phenomenon create new regions (areas) by combining with one another in accordance with the above-mentioned rules. These, in turn, in the next steps of the network model development, search for new connections according to the same rules. In this way, subsequent levels of the aggregation of values representing specific phenomena occurring within the space emerge [40].

\section{The Network Model Construction according to the Minimum Value Increase Path}

The development of the network model and new regions according to this path involves the generation of a connection of each field, in turn, with a selected neighboring field, according to the minimum value increase path. The newly emerged fields (regions) search for new connections according to the same principles [40]. 
It was assumed that the space under analysis was represented by basic fields to which the values obtained from the assessment of the landscape's aesthetic value have been assigned, and which differentiate the geographical space in the landscape's value aspect. The construction of the model using the minimum value increase path commenced with the search for relationships and connections between each field (Fig. 3a).

a)

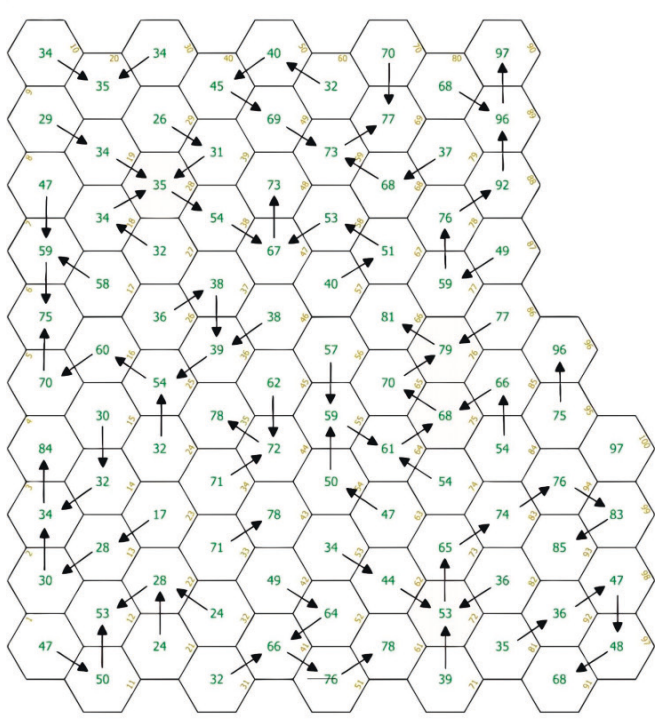

b)

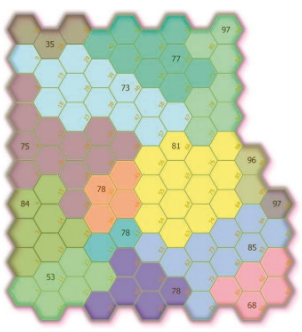

d)

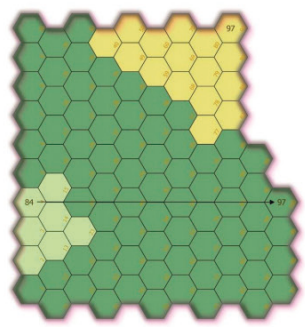

c)

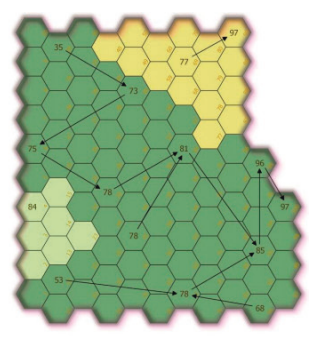

e)

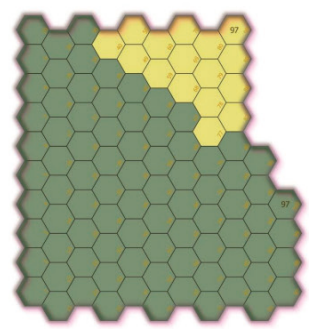

Fig. 3. The network model built with the use of the minimum value increase path (a-e). Key: $\rightarrow-$ the arrows show the direction of the connection according to the principle of minimum increase in value; the same color of the hexagons means new regions which were created in the follow stages of aggregation $(b-e)$. An analysis made in QGis

At the stage of revealing the relationships, 82 fields (nodes) found a connection according to the minimum value increase path (Fig. 3a). In the first stage of aggregation, 15 new regions (fields) emerged (Fig. 3b). Characteristics of the developed network are provided in Table 3.

The second stage of value aggregation revealed three new regions (fields) (Fig. 3c, d). At this stage, one strong node with 76 connections emerged. The last, third stage of aggregation revealed two regions (fields) represented by two strong nodes with 15 and 83 connections (Fig. 3e). This means that it is those particular nodes with numbers 90 and 100 that are the most valuable within the structure of a particular network and that the walking pathways should be designed towards them. 
Table 3. Characteristics of the developed network model

\begin{tabular}{|c|c|c|c|}
\hline Number of stage & $\begin{array}{l}\text { Number of } \\
\text { regions }\end{array}$ & $\begin{array}{c}\text { Number of fields } \\
\text { (nodes) }\end{array}$ & $\begin{array}{l}\text { Number of } \\
\text { connections }\end{array}$ \\
\hline \multirow{11}{*}{$\begin{array}{l}\text { Stage } 1 \text { of aggregation } \\
15 \text { regions remerged } \\
(15 R)\end{array}$} & 1 & 1 & 0 \\
\hline & 2 & 2 & 1 \\
\hline & 1 & 3 & 2 \\
\hline & 1 & 4 & 3 \\
\hline & 1 & 5 & 4 \\
\hline & 2 & 6 & 5 \\
\hline & 2 & 7 & 6 \\
\hline & 1 & 9 & 8 \\
\hline & 1 & 10 & 9 \\
\hline & 1 & 12 & 11 \\
\hline & 2 & 13 & 12 \\
\hline \multirow{3}{*}{$\begin{array}{l}\text { Stage } 2 \text { of aggregation } \\
(3 R)\end{array}$} & 1 & 7 & 6 \\
\hline & 1 & 16 & 15 \\
\hline & 1 & 77 & 76 \\
\hline \multirow{2}{*}{$\begin{array}{l}\text { Stage } 3 \text { of aggregation } \\
(2 \mathrm{R})\end{array}$} & 1 & 16 & $\begin{array}{c}15 \\
\text { (node no. 90) }\end{array}$ \\
\hline & 1 & 84 & $\begin{array}{c}83 \\
\text { (node no. 100) }\end{array}$ \\
\hline
\end{tabular}

Based on the network model developed in this manner, a number of scenarios of the route of walking pathways were developed (Fig. $4 \mathrm{a}-\mathrm{c}$ ). This network model offered the opportunity to design them in such a manner that the route runs through the most attractive fields (with a large number of connections), with increasing aesthetic sensations experienced by the person walking. Designing the pathways on such a network model excluded the possibility of omitting the most attractive places due to the landscape's aesthetic value. Proposals for the route of walking pathways developed using the landscape's aesthetic value network model are presented in Figures $4 \mathrm{~b}$ and $4 \mathrm{c}$. These cartographic models, based on the theory of model construction using the minimum value increase path, can be the basic material for planning operations in the field of designing the recreational space as well as walking or educational pathways. 


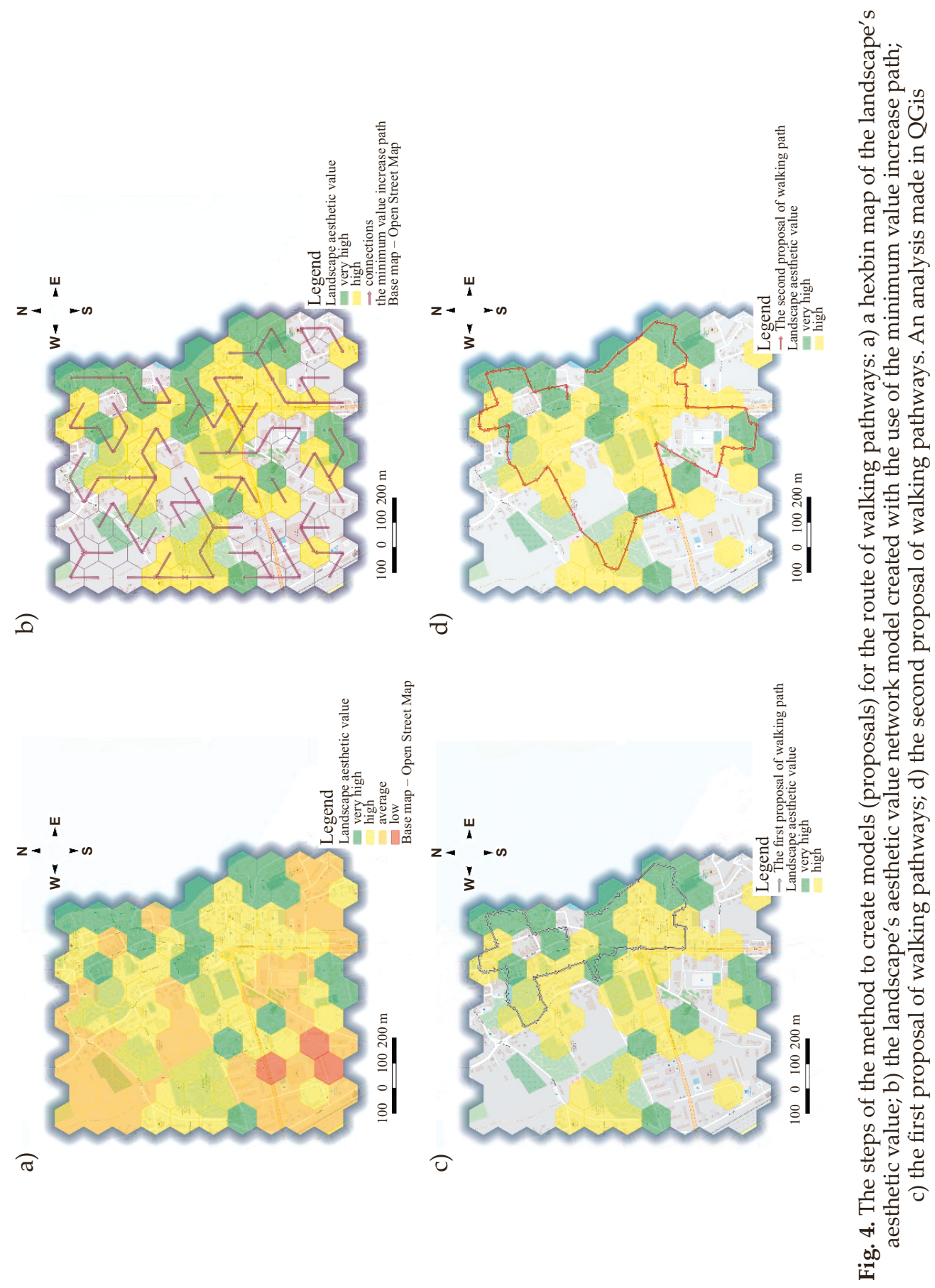




\section{Conclusions}

The aim of the study was to examine the possibility of applying the selected components of the theory of six value aggregation paths in designing walking pathways, based on the specific example of a tourist resort. In order to construct a model for subsequent analyses and designing a walking pathway, data on the landscape's aesthetic value were collected. Wejchert's impression curve method modified by Bajerowski was employed in the study. 100 scenic points representing hexagonal basic assessment points were subjected to an assessment and a hexbin map of the landscape's aesthetic value within the area under analysis was developed. Using the minimum value increase path, which is a component of the six value combination paths, a network of connections between the landscape's aesthetic value was established. Based on the network model developed in this manner, two proposals for carrying walkway pathway routes within the area under analysis were developed.

The conducted study leads to the conclusion that the minimum value increase path used to set out the walking pathway route may create a good basis for designing walking pathways. Not only is this manifested in the varied route of the pathway but also in the design of the pathway in such a way so that the landscape's aesthetic value increases, or slightly decreases, from a point to another point. Sometimes, the pathway route must be carried through a point where the value is, nonetheless, much lower, as it is illogical or simply problematic to avoid such a point. In such a case, the method shows in a tangible way where the landscape's aesthetic value should be increased, or where the components of an educational pathway should be enriched. The placing (locating) of thematic materials or exposition in this less attractive point will enable focusing on these particular components and not on the aesthetic shortcomings of the landscape. Wejchert's impression curve and the subsequently constructed network model provide the entities managing the particular space with an excellent tool for planning operations, for example, establishing a ranking of places that need to be reinforced (which means that the aesthetic value of these particular places, or places seen from them, needs to be increased). The developed pathway variants are linked into a logical sequence resulting from the path of a minimum increased in the landscape's aesthetic value. A walking person's aesthetic sensations gradually increase, which brings about the effect of satisfaction and contentment leading to the proverbial situation where "the last impression is the most important". Designing a walking trail, faithful to the principle of the increase in aesthetic value, encourages walking visitors to not stray from the pathway. It would be illogical to show the most attractive places at the beginning of the route. In addition, the use of hexagonal basic fields enables the design of various route lengths and the optimization of time by adapting the model to a specific group of recipients. The network developed in this way offers the opportunity to carry the walking pathway route using the existing road and pavement network. 
The length of the route and points are designated on the basis of a network of basic evaluation fields. The adjustment of the network and the size of the basic evaluation fields is made at the beginning of the analytical process. Depending on needs, these fields may be larger or smaller, which leads to decreasing or increasing the distance between the evaluation points. Fields of different size will be applied to a smaller area, like the one presented in the article, and for a particularly big area.

The method takes into consideration the occurrence of natural barriers, e.g. when the whole hexagon includes a lake. A part of the suggested pathway modeling method, which also suggests using one of the algorithms of the six ways theory, works for the given network of basic fields. Barriers should also be considered by excluding the area from the analyses.

An important asset of pathways designed in such a manner is the opportunity to prepare the optimum form of their presentation, e.g. in the form of a guide, including an online guide. Additionally, the network structure and the digital vector model offer opportunities for:

- carrying out additional analyses to determine the nature of the networks under development (random or scale-free), and the identification of the main nodes and centers of this network i.e. the most important points that are of strategic importance in the context of the entire network structure functioning;

- taking virtual walks, for example in the Covid-19 era;

- carrying out planning operations related to the development of the asset regarding the landscape's aesthetic value, and taking remedial measures using cartographic models (maps) and network models in spatial terms;

- the easy and convenient as well as scientifically justified development of various models and scenarios of the walking pathway routes, including educational ones;

- the construction of the landscape's aesthetic value network models using the other five paths of combining these values and their analysis; the comparison of network models, e.g. the minimum increase in the landscape's aesthetic value with a network constructed using the path of the minimum decrease in this value, can yield numerous conclusions.

This method assumes that at the stages of searching for relationships with the connections in constructing the network, a field can only connect to a single neighboring field. This creates a certain problematic situation, where two or more neighboring fields have the same value. The solution to this problem is a thorough analysis of the location, and an appropriate choice made by the person who models the network and, on its basis, the pathway.

The conducted case study leads to the conclusion that this methodology can be an appropriate and useful tool in designing walking pathways. 


\section{References}

[1] Polskie Towarzystwo Turystyczno-Krajoznawcze: Instrukcja znakowania szlaków turystycznych. Wydawnictwo PTTK „Kraj”, Warszawa 2014. https://www.pttk.pl/pttk/przepisy/instrukcja_znakowania_szlakow_pttk_2014.pdf [access: 14.12.2020].

[2] Report of the World Commission on Environment and Development: Our common future. http://www.ask-force.org/web/Sustainability/Brundtland-Our-Common-Future-1987-2008.pdf [access: 10.12.2020].

[3] Cash D.W., Clark W.C., Alcock F., Dickson N.M., Eckley N., Guston D.H., Jäger J., Mitchell R.B.: Knowledge systems for sustainable development. Proceedings of the National Academy of Sciences, vol. 100(14), 2003, pp. 8086-8091.

[4] Baranowska-Janota M., Korzeniak G.: Zasady turystycznego użytkowania i ochrony parków krajobrazowych. IGPiK, Kraków 1991.

[5] Polucha I., Marks E., Jaszczak A., Elkhatib A.: Zasady projektowania ścieżek dydaktycznych o tematyce zdrowotnej na obszarach leśnych. Problemy Ekologii Krajobrazu, vol. 34, 2012, pp. 313-316.

[6] Ptaszycka-Jackowska D., Baranowska-Janota M.: Zasady korzystania z przyrodniczych obszarów chronionych. Instytut Gospodarki Przestrzennej i Komunalnej, Warszawa 1989.

[7] Cymerman R., Falkowski J., Hopper A.: Krajobrazy wiejskie. Wydawnictwo ART, Olsztyn 1992.

[8] Bajerowski T., Biłozor A., Cieślak I., Sanetra A., Szczepańska A.: Ocena i wycena krajobrazu. Educaterra, Olsztyn 2007.

[9] Bogdanowski J.: Architektura krajobrazu. Państwowe Wydawnictwo Naukowe, Warszawa 1973.

[10] Arthur L.M., Daniel T.C., Boster R.S.: Landscape assessment: a critical review of research and methods. Landscape Management, vol. 4, 1977, pp. 109-129.

[11] Zube E.H., Sell J.L., Taylor J.G.: Landscape perception: research, application and theory. Landscape Planning, vol. 9(1), 1982, pp. 1-33.

[12] Hopfer A., Cymerman R., Nowak A.: Ocena $i$ waloryzacja gruntów wiejskich. Państwowe Wydawnictwo Rolnicze i Leśne, Warszawa 1982.

[13] Wojciechowski K.H.: Problemy percepcji i oceny estetycznej krajobrazu. Rozprawy Wydziału Biologii i Nauk o Ziemi - Uniwersytet Marii Curie-Skłodowskiej. Rozprawy Habilitacyjne, 28, UMCS, Lublin 1986.

[14] Bajerowski T.: Ocena, ochrona i kształtowanie krajobrazu wiejskiego, jako składnik programowania prac urzadzeniowo-rolnych. Uniwersytet Warmińsko-Mazurski, Olsztyn 1991 [Ph.D. thesis].

[15] Bajerowski T.: Wycena krajobrazu. Rynkowe aspekty oceny i waloryzacji krajobrazu. Educaterra, Olsztyn 2000. 
[16] Kowalczyk A.: Geografia turyzmu. Wydawnictwo Naukowe PWN, Warszawa 2000.

[17] Senetra A.: Zagospodarowanie rekreacyjne jako element rozwoju przestrzeni wiejskiej na przykładzie regionu warmińsko-mazurskiego. Uniwersytet Warmińsko-Mazurski, Olsztyn 2001 [Ph.D. thesis].

[18] Senetra A., Cieślak I.: Kartograficzne aspekty oceny i waloryzacji przestrzeni. Wydawnictwo Uniwersytetu Warmińsko-Mazurskiego, Olsztyn 2004.

[19] Aguilera F., Valenzuela L.M., Botequilha-Leitão A.: Landscape metrics in the analysis of urban land use patterns: A case study in a Spanish metropolitan area. Landscape and Urban Planning, vol. 99(3-4), 2011, pp. 226-238.

[20] Balon J., Krąż P.: Ocena jakości krajobrazu - dobór prawidłowych jednostek krajobrazowych. [in:] Identyfikacja i waloryzacja krajobrazów - wdrażanie Europejskiej Konwencji Krajobrazowej: referaty konferencyjne, Generalna Dyrekcja Ochrony Środowiska, Warszawa 2013, pp. 62-67.

[21] Kowalczyk A.M.: The analysis and creation of landscape aesthetic value network models as important elements of sustainable urban development. Environmental Engineering. Proceedings of the International Conference on Environmental Engineering - ICEE, vol. 9, 2014, pp. 1-7.

[22] Tveit M.S., Ode S.Å., Hagerhall C.M.: Scenic beauty: Visual landscape assessment and human landscape perception. [in:] Steg L., de Groot J.I.M. (eds.), Environmental Psychology: An Introduction, John Wiley \& Sons, 2018, pp. 45-54.

[23] Krause C.L.: Our visual landscape: Managing the landscape under special consideration of visual aspects. Landscape and Urban Planning, vol. 54(1-4), 2001, pp. 239-54.

[24] Palmer J.F.: Stability of landscape perceptions in the face of landscape change. Landscape and Urban Planning, vol. 37(1-2), 1997, pp. 109-113.

[25] Cassatella C., Peano A.: Landscape Indicators. Springer, 2011.

[26] Ervin S.M.: Digital landscape modeling and visualization: a research agenda. Landscape and Urban Planning, vol. 54(1-4), 2001, pp. 49-62.

[27] Bryan B.A.: Physical environmental modeling, visualization and query for supporting landscape planning decisions. Landscape and Urban Planning, vol. 65(4), 2003, pp. 237-259.

[28] Lovett A., Appleton K., Warren-Kretzschmar B., Von Haaren C.: Using $3 D$ visualization methods in landscape planning: an evaluation of options and practical issues. Landscape and Urban Planning, vol. 142, 2015, pp. 85-94.

[29] Orland B.: Synthetic landscapes. [in:] Marans R.W., Stokols D. (eds.), Environmental Simulation: Research and Policy Issues, Plenum Press, 1993, pp. 213-250.

[30] Daniel T.C.: Whither scenic beauty? Visual landscape quality assessment in the 21st century. Landscape and Urban Planning, vol. 54(1-4), 2001, pp. 267-281. 
[31] Ghadirian P., Bishop I.D.: Integration of augmented reality and GIS: anew approach to realistic landscape visualisation. Landscape and Urban Planning, vol. 86(3-4), 2008, pp. 226-232.

[32] Palmer J.F.: The contribution of a GIS-based landscape assessment model to a scientifically rigorous approach to visual impact assessment. Landscape and Urban Planning, vol. 189, 2019, pp. 80-90.

[33] Telega A., Telega I., Bieda A.: Measuring Walkability with GIS - Methods Overview and New Approach Proposal. Sustainability, vol. 13(4), 2021, art. no. 1883.

[34] Dörrzapf L., Kovács-Győri A., Resch B., Zeile P.: Defining and assessing walkability: a concept for an integrated approach using surveys, biosensors and geospatial analysis. Problemy Rozwoju Miast, t. 62(1), 2019, pp. 5-15.

[35] Skalski J.A.: Analiza percepcyjna krajobrazu jako działalność twórcza inicjujaca proces projektowania. Wydawnictwo Szkoły Głównej Gospodarstwa Wiejskiego, Warszawa 2007.

[36] Lynch K., Appleyard D., Myer J.R.: The view from the road. Massachusetts Institute of Technology, Massachusetts 1964.

[37] Wejchert K.: Elementy kompozycji urbanistycznej. Arkady, Warszawa 1974.

[38] Böhm A.: Architektura krajobrazu - jej początki i rozwój. Skrypt dla Studentów Wyższych Szkół Technicznych, Politechnika Krakowska im. Tadeusza Kościuszki, Kraków 1994.

[39] Kowalczyk A., Bajerowski T., Czyża S.: Data sources for the identification and modelling of open space structures in urban areas. [in:] 26 $6^{\text {th }}$ Geographic Information Systems Conference and Exhibition "GIS ODYSSEY 2019": Conference proceedings, Information Technology Society - GIS Forum, Croatia, Zagreb 2019, pp. 121-131.

[40] Kowalczyk A.M., Bajerowski T.: Development of the Theory of Six Value Aggregation Paths in Network Modeling for Spatial Analyses. ISPRS International Journal of Geo-Information, vol. 9, no. 4, 2020, art. no. 234. 